\title{
Effect of different single herbicide doses on sugar beet yield, quality and associated weeds
}

\author{
E. M. Abd El Lateef ${ }^{*}$ (D, B. B. Mekki ${ }^{1}$, M. S. Abd El-Salam ${ }^{1}$ and I. M. El-Metwally ${ }^{2}$
}

\begin{abstract}
Background: The objective of this work is to identify the most proper herbicidal treatment on sugar beet to compare different single weed control herbicide doses on sugar beet traits and associated weeds as well as yield and quality under sandy soil conditions. Therefore, two field experiments were conducted during the winter seasons of 2017/2018 and 2018/2019 at the Experimental Farm of the National Research Centre, El-Beheira Governorate. Tigro at 1.0 and $0.750 \mathrm{Ifed}^{-1}$, Betasana-Trio at 0.675 and at $0.9 \mathrm{I} \mathrm{fed}^{-1}$, Select Super at 0.5 and $0.375 \mathrm{I} \mathrm{fed}^{-1}$ and Betanal MaxxPro at $0.5 \mathrm{I} \mathrm{fed}^{-1}$ besides the unweeded and hand weeded twice were used.

Results: The results showed that the herbicides Betasana-Trio at $0.9 \mathrm{I} \mathrm{fed}^{-1}$, Tigro at $1.0 \mathrm{l} \mathrm{fed}^{-1}$ and Betasana-Trio at $0.675 \mathrm{I} \mathrm{fed}^{-1}$ when sprayed twice could effectively and/or completely eliminate the broadleaved weeds associated with sugar beet plants. Moreover, the results indicated and confirmed that Tigro and Betasana-Trio herbicides are effective in controlling broadleaved weeds. Similar tendency was recorded for the narrow-leaved weeds, where Select

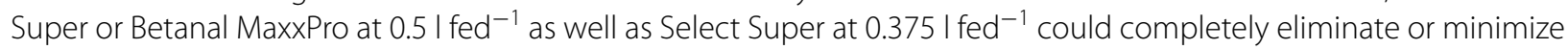
the narrow-leaved weeds associated with sugar beet plants. The greatest significant root length, root diameters and root yield plant ${ }^{-1}$ were recorded when hand weeding twice followed by Betanal MaxxPro at $0.5 \mathrm{I} \mathrm{fed}^{-1}$ without significant differences. Gross sugar \% ranged between 12.08 and $15.7 \%$ and extractable sugar \% ranged between 8.97 and $13.8 \%$ for Betasana-Trio at $0.09 \mathrm{I} \mathrm{fed}^{-1}$ and Betanal MaxxPro at $0.5 \mathrm{I} \mathrm{fed}^{-1}$.

Conclusion: Betanal MaxxPro gave the highest values of root and biological yield ton $\mathrm{fed}^{-1}$. Betanal MaxxPro followed by hand weeding treatment twice resulted in the greatest sugar yield $\mathrm{fed}^{-1}$. The highest sugar yield resulted from the herbicidal treatment with Betanal MaxxPro or Tigro at $1.0 \mathrm{l} \mathrm{fed}^{-1}$, which gave the greatest gross and extractable sugar yield fed ${ }^{-1}$ and exceeded the hand weeding treatment by 10.4 and $7.8 \%$.
\end{abstract}

Keywords: Sugar beet, Weeds, Herbicide, Yield, quality

\section{Background}

It is well known that weeds interfere with crop plants causing serious impacts either in the competition for light, water, nutrients and space or in the allelopathy. Weed suppression by shading only begins after the canopy of sugar beet leaves grown over the rows and early

\footnotetext{
*Correspondence: profabdellateef@gmail.com

${ }^{1}$ Field Crops Res. Dept., Agric. Div., National Research Centre, 33

El-Behooth St., Giza, Egypt

Full list of author information is available at the end of the article
}

coverage of field. Faster growth of weeds is disadvantageous for light and hence photosynthesis needed for sugar beet plants. Through this light deprivation, less energy is available to crop plant for metabolic production and hence growth, yield and quality of sugar beet will be reduced. In addition, weeds with branched, vigorous root systems inhibit the development of sugar beet plants through severe nutrition deprivation. Up to $100 \%$ of the crop yield may be lost because of weed competition if weed control is poor or not performed 
at all (Schweizer and Dexter 1987). Special attention on weed control has to be paid during the critical period at an early stage of sugar beet development (Bezhin et al. 2015), a period of the first 60 days after emergence when sugar beet does not tolerate competitive interactions with weeds without losing yield (Kobusch 2003; Petersen 2008; Jalali and Salehi 2013).

Competition between sugar beet and annual weeds could be responsible for sugar yield reductions of 26-100\% (Cioni and Maines 2011). Weed control in crops is mainly based on the use of herbicides because they are efficient and easily applied (Lodovichi et al. 2013). The use of herbicides may reduce yield losses, as herbicides can reduce the weed infestation (Mehmeti 2004). Majidi et al. (2011) showed that using a combination of broadleaved herbicides-controlled weeds and root yields to be increased. Herbicidal treatment can result in low crop interference with weeds (Jursík et al. 2008). Majidi et al. (2017) reported that several herbicides are registered for selective weed control in sugar beet; however, no single chemical herbicide can control all weeds in beet fields.

Hand hoeing is still the conventional weeds control practice in sugar beet fields in Egypt. In the last decades, the hand labor is becoming scarce and their wages have been increased. However, the manual weeding could not be perfectly provided. This in turn presents to view the needs for another reasonable alternative tool. Herbicide treatment alone surpassed some hand hoeing treatments. In this respect, Abo El-Hassan (2010) found that root length, root diameter, root weight, top fresh weight, top yield, root yield and sugar yield of sugar beet were significantly affected by weed control treatments. Also, Tagour et al. (2012) found that hand hoeing twice with mulching gave the highest values of tops, roots, biological and sugar yields. May (2003) reported that sugar beet is a poor competitor with weeds in arable fields because it is slow growing early in the season and has a low canopy. Sugar beet is not competitive with emerging weeds until it has at least eight true leaves. The total potential losses from weeds are estimated between 50 and $100 \%$ of the potential crop yield (May 2001).

Therefore, the objective of this work is to identify the most proper herbicidal treatment on sugar beet yield and quality under sandy soil conditions.

\section{Methods}

During the winter seasons of 2017/2018 and 2018/2019, two field experiments were conducted at the Experimental Farm of the National Research Centre (latitude of $30.87^{\circ}$ $\mathrm{N}$ and longitude of $31.17^{\circ} \mathrm{E}$ and mean altitude $21 \mathrm{~m}$ above sea level), El-Beheira Governorate, to evaluate different herbicidal treatments on sugar beet yield characters and associated weeds. The experimental soil was sandy, and the mechanical and chemical analysis of the soil is presented in Table 1.

Sugar beet cultivar Baraka was sown in hills $25 \mathrm{~cm}$ apart at a rate of $2 \mathrm{~kg} \mathrm{fed}^{-1}$ by hand in rows in 21 and 29 November in 2017/2018 and 2018/2019 seasons, respectively. The experimental design was a completely randomized block design in four replicates. The common, trade and chemical names of used herbicides as well as mode of action, rate and time of application are listed in Table 2.

Single weed control herbicide doses were used, and the experiment included the following treatments:

1) Tigro $1.0 \mathrm{l} \mathrm{fed} \mathrm{f}^{-1}$

2) Tigro $0.7501 \mathrm{fed}^{-1}$.

3) Betasana-Trio $0.91 \mathrm{fed}^{-1}$.

4) Betasana-Trio $0.675 \mathrm{l} \mathrm{fed}^{-1}$.

5) Select Super $0.51 \mathrm{fed}^{-1}$.

6) Select Super $0.3751 \mathrm{fed}^{-1}$.

7) Betanal MaxxPro $0.51 \mathrm{fed}^{-1}$.

8) Hand weeding twice.

9) Unweeded control.

Herbicides were sprayed by Knapsack sprayer (at 200 $\mathrm{L} \mathrm{fed}{ }^{-1}$ ). The normal cultural practices for growing sugar beet in sandy soil were applied as recommended, except for weed control measures.

\section{Studied characters Weed flora}

A sample of weeds in $1 \mathrm{~m} 2$ was taken from each experimental unit to determine the number and fresh weights of broadleaved, narrow-leaved and total number of weeds. Thereafter, the weed samples were dried and dry weights were recorded.

The eradication $\%$ of weeds was calculated as follows:

Table 1 Mechanical and chemical analysis of experimental soil

\begin{tabular}{llllllllll}
\hline Sand \% & Silt \% & Clay \% & $\mathbf{p H}$ & Organic matter, $\%$ & $\mathbf{C a C o}_{\mathbf{3}} \%$ & E.C. ds $/ \mathbf{m}$ & Soluble N, ppm & Available P, ppm & Exchangeable K, ppm \\
\hline 91.2 & 3.7 & 5.1 & 7.3 & 0.3 & 1.4 & 0.3 & 8.1 & 3.2 & 20 \\
\hline
\end{tabular}


Table 2 Common, trade and chemical names of the herbicides used as well as mode of action, rate and time of application

\begin{tabular}{|c|c|c|c|c|c|}
\hline Common name & Trade name & Chemical name & Mode of action & Rate of application & Time of application \\
\hline Desmedipham & Betanal MaxxPro & $\begin{array}{l}\text { Desmedipham-47 g / } \\
\text { Ethofumesate-75 g/l } \\
\text { Lenacil-27 g/l } \\
\text { Phenmedipham-60 g / }\end{array}$ & $\begin{array}{l}\text { Classical photosynthesis } \\
\text { inhibitors }\end{array}$ & $500 \mathrm{~cm} \mathrm{fed}^{-1}$ & $\begin{array}{l}\text { At the age of 2-3 real leaves } \\
\text { at sugar beet }\end{array}$ \\
\hline Ethofumesate & Betasana-Trio & $\begin{array}{l}\text { Ethofumesate-115 g/l } \\
\quad(11.5 \% \mathrm{w} / \mathrm{w}) \\
\text { Phenmedipham-75 g/l } \\
(7.65 \% \mathrm{w} / \mathrm{w}) \\
\text { Desmedipham-15 g/l } \\
(1.55 \% \mathrm{w} / \mathrm{w})\end{array}$ & $\begin{array}{l}\text { Classical photosynthesis } \\
\text { inhibitors }\end{array}$ & $900 \mathrm{~cm}+900 \mathrm{~cm} \mathrm{fed}^{-1}$ & $\begin{array}{c}\text { At the age of two real leaves } \\
\text { on sugar beet and repeat } \\
\text { treatment after } 8 \text { days }\end{array}$ \\
\hline Phenmedipham & Tigro 27.4/EC & $\begin{array}{l}\text { - } 91 \mathrm{~g} / \mathrm{l} \\
\text { Desmedipham-71 g/l } \\
\text { Ethofumesate-112 g/l }\end{array}$ & $\begin{array}{l}\text { Classical photosynthesis } \\
\text { inhibitors }\end{array}$ & $1.0 \mathrm{Ifed}^{-1}$ & $\begin{array}{l}\text { At the age of two real leaves } \\
\text { on sugar beet }\end{array}$ \\
\hline Clethodim & Select Super & $\begin{array}{l}\text { ( } \pm \text { )-2-[(E)-1-[(E)-3-chloroal- } \\
\text { lyloxyimino]propyl]-5-[2- } \\
\text { (ethylthio)propyl]-3- } \\
\text { hydroxycyclohex- } \\
\text { 2-enone }\end{array}$ & Lipid biosynthesis inhibitors & $500 \mathrm{~cm} \mathrm{fed}^{-1}$ & $\begin{array}{l}\text { At the age of 2-4 real leaves } \\
\text { of weeds }\end{array}$ \\
\hline
\end{tabular}

Eradication \% (fresh weight $\left.\mathrm{m}^{-2}\right)$

$=($ fresh weight of weeds the unweeded

-fresh weight of weeds treatment)/

fresh weight of weeds the unweeded $\times 100$

Eradication \% (dry weight $\mathrm{m}^{-2}$ )

$=($ dry weight of weeds the unweeded

- dry weight of weeds treatment)/

dry weight of weeds the unweeded $\times 100$

Eradication \% (total No. of weeds $\mathrm{m}^{-2}$ )

$=($ No. of weeds the unweeded

- No. of weeds of the unweededtreatment) /

No. of weeds the unweeded $\times 100$.

- Plant samples were taken from three replicates, and ten plants were taken from each experimental unit to estimate root characters: root length $(\mathrm{cm})$, root diameter $(\mathrm{cm})$, root weight $(\mathrm{g})$ and top weight per plant $(\mathrm{g})$.

- Yield per feddan: The number of plants in the experimental unit area was counted, top and roots weights of $3 \times 3.5 \mathrm{~m}$ were determined, and then, total yield was calculated.

- Total chlorophyll content of sugar beet leaves was determined in both seasons as SPAD value was determined at 90 days by a chlorophyll meter (SPAD-502, Minolta Camera Co., Osaka, Japan, Minolta Co., 1989).
- Chemical composition of the roots: A sample of $5 \mathrm{~kg}$ of selected treatments was taken from the roots for analysis done by the sugar factory in El-Nubaria to determine chemical composition of the roots in both seasons. The determinations included polarity (gross sugar \%), Qz \% (juice purity \%), Na, K and $\alpha$-amino-N. Sugar yield per feddan was calculated by multiplying gross sugar \% by root yield $\mathrm{fed}^{-1}$.

\section{Statistical analysis}

The analysis of variance was carried out using MSTATC Computer Software (MSTAT-C, 1988) after testing the homogeneity of the error by Bartlett's test; combined analysis for both seasons was done. Means of the different treatments were compared using the least significant difference (LSD) at 5\% level.

\section{Results}

\section{Effect of weed control treatments on weed traits}

The dominant weed species in the experiment included common sweet clover (Melilotus indica L.), wild beet (Beta vulgaris L.), Greater Ammi (Ammi majus L.) and London rocket (Sisymbrium irio L.) as broadleaved weeds and wild oat (Avena fatua L.) as well as ryegrass (Lolium temulentum L.) as narrow-leaved weeds.

Data in Table 3 show that weed control treatments differed significantly in their effect on fresh and dry weight of broadleaved, narrow-leaved and total weeds as well as number of broadleaved, narrow-leaved and total weeds $\mathrm{m}^{-2}$ after 90 days from sowing. The data showed that the herbicides Betasana-Trio at $0.9 \mathrm{l} \mathrm{fed}^{-1}$, Tigro at $1.0 \mathrm{l}$ fed $^{-1}$ and Betasana-Trio at $0.675 \mathrm{l} \mathrm{fed}^{-1}$ could effectively or reasonably eliminate the broadleaved weeds associated 


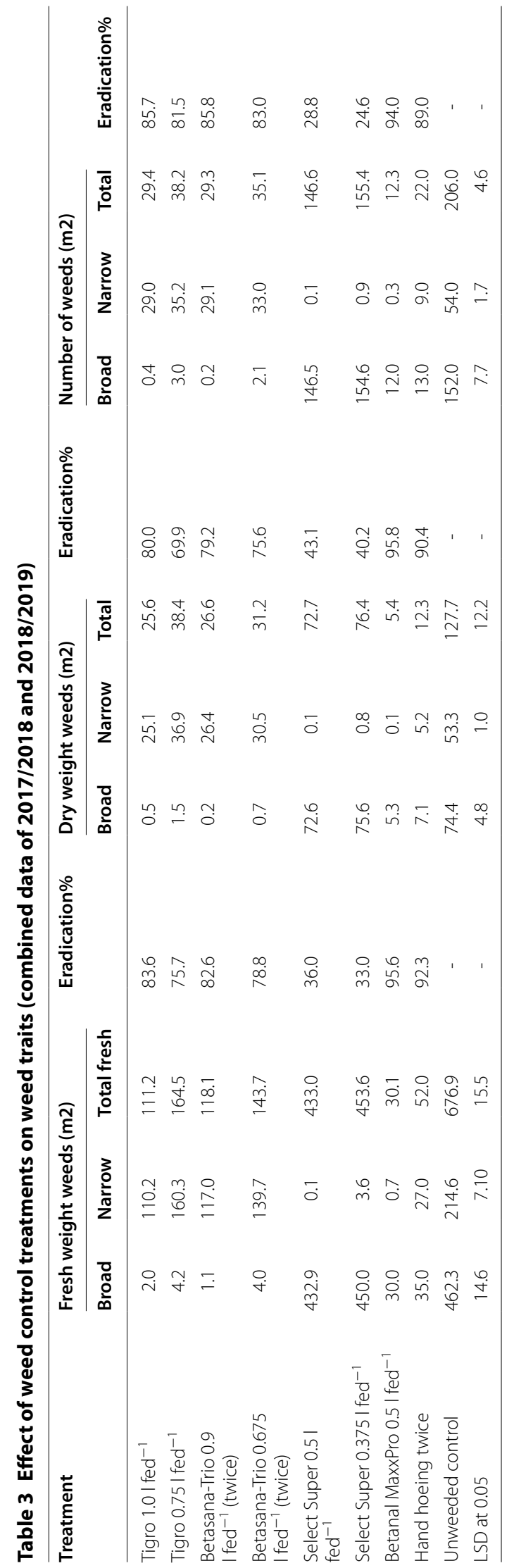


with sugar beet plants so the number or fresh and dry weights was minimized when Betasana-Trio at 0.91 $\mathrm{fed}^{-1}$ was applied. Similar tendency was recorded for the narrow-leaved weeds, where Select Super $0.5 \mathrm{l} \mathrm{fed}^{-1}$ or Betanal MaxxPro at $0.5 \mathrm{l} \mathrm{fed}^{-1}$ as well as Select Super at $0.375 \mathrm{l} \mathrm{fed}^{-1}$ could completely eliminate or minimize the narrow-leaved weeds. Data in the same table show that Betanal MaxxPro treatment recorded the highest eradication percent of the total fresh and dry weights as well as number of weeds $\mathrm{m}^{-2}$ followed by that of hand hoeing treatment, Betasana-Trio at $0.9 \mathrm{l} \mathrm{fed}^{-1}$ and Tigro at $1.0 \mathrm{l}$ $\mathrm{fed}^{-1}$, respectively.

\section{Effect of weed control treatments on sugar beet crop characteristics Chlorophyll content}

The chlorophyll content data in Table 4 expressed as SPAD reading indicate that there was no clear tendency of the tested herbicides in their effect on chlorophyll content of sugar beet leaves. However, Tigro and BetasanaTrio herbicides at their high doses of application (1.0 and $0.91 \mathrm{fed}^{-1}$, respectively) recorded the greatest chlorophyll content compared with the other weed control treatments (Table 4), whereas the lowest chlorophyll content was recorded by the unweeded control. There was insignificant difference among the other herbicidal treatments and hand hoeing twice.

\section{Yield characteristics}

Data in Table 4 show significant differences among weed control treatments in their effect on sugar beet root length and diameter. The highest root length and diameter were recorded when hand hoeing twice and Betanal MaxxPro were applied, respectively. The difference between Betasana-Trio treatment at $0.675 \mathrm{l} \mathrm{fed}^{-1}$ and hand weeding twice in root length and diameter was insignificant. The differences among other treatments were significant in these criteria.

The statistical analysis of the data in Table 4 revealed significant differences among weed control treatments in their effect on sugar beet yield characters. Significant differences in root and shoot yields plant ${ }^{-1}$ were detected. The greatest significant root yield plant ${ }^{-1}$ was recorded when Betanal MaxxPro and hand hoeing twice were applied, respectively. The differences among other weed control treatments were significant. The highest shoot yield plant ${ }^{-1}$ was obtained when Tigro at $1.0 \mathrm{l} \mathrm{fed}^{-1}$ and Select Super at $0.5 \mathrm{l} \mathrm{fed}^{-1}$ were sprayed, while the lowest fresh weight plant $^{-1}$ was recorded when unweeded treatment was applied.

The maximum shoot yield fed $^{-1}$ was found when the Tigro at $1.0 \mathrm{l} \mathrm{fed}^{-1}$ was applied followed by Betanal MaxxPro treatment, Select Super at $0.51 \mathrm{fed}^{-1}$ and hand hoeing twice; however, the differences among other treatments were insignificant in their effect on shoot yield $\mathrm{fed}^{-1}$ (Table 4). Concerning the effect of weeding practices on sugar beet root yield $t \mathrm{fed}^{-1}$, all weeded plots produced greater root yields than the weedy check one. Applying Betanal MaxxPro, hand hoeing twice, Tigro at

Table 4 Effect of different herbicidal treatments on sugar beet crop characteristics (combined data of $2017 / 2018$ and 2018/2019)

\begin{tabular}{|c|c|c|c|c|c|c|c|c|}
\hline Treatment & SAPD value & $\begin{array}{l}\text { Root } \\
\text { length } \\
(\mathrm{cm})\end{array}$ & $\begin{array}{l}\text { Root diameter } \\
(\mathrm{cm})\end{array}$ & $\begin{array}{l}\text { Root yield } \\
\text { plant }^{-1}(g)\end{array}$ & $\begin{array}{l}\text { Shoot yield } \\
\text { plant }^{-1}(g)\end{array}$ & $\begin{array}{l}\text { Root yield fed }{ }^{-1} \\
\text { (t) }\end{array}$ & $\begin{array}{l}\text { Shoot } \\
\text { yield } \\
\text { fed }^{-1} \\
\text { (t) }\end{array}$ & $\begin{array}{l}\text { Biological yield } \\
\text { fed }^{-1} \\
\text { (t) }\end{array}$ \\
\hline Tigro $1.0 \mathrm{I} \mathrm{fed}^{-1}$ & 47.4 & 28.2 & 7.6 & 391.4 & 195.8 & 27.0 & 13.9 & 40.9 \\
\hline Tigro 0.75 I fed $\mathrm{f}^{-1}$ & 44.2 & 26.8 & 7.6 & 348.8 & 183.8 & 24.3 & 10.2 & 34.5 \\
\hline $\begin{array}{l}\text { Betasana-Trio } 0.9 \\
\text { | fed }^{-1} \text { (twice) }\end{array}$ & 47.1 & 25.8 & 7.0 & 384.4 & 178.2 & 25.3 & 9.79 & 35.09 \\
\hline $\begin{array}{l}\text { Betasana-Trio } 0.675 \\
\text { I fed } \text { f }^{-1} \text { (twice) }\end{array}$ & 44.4 & 26.3 & 7.2 & 282.9 & 159.8 & 21.25 & 8.71 & 29.96 \\
\hline Select Super $0.5 \mathrm{I} \mathrm{fed}^{-1}$ & 41.3 & 26.3 & 7.2 & 282.9 & 189.8 & 21.25 & 13.2 & 34.45 \\
\hline $\begin{array}{l}\text { Select Super } 0.375 \\
\text { I fed }^{-1}\end{array}$ & 42.8 & 25.8 & 6.6 & 317.6 & 178.9 & 19.1 & 9.79 & 28.89 \\
\hline $\begin{array}{l}\text { Betanal MaxxPro } 0.5 \\
\text { | fed }^{-1}\end{array}$ & 46.8 & 31.8 & 8.6 & 465.0 & 170.6 & 33.9 & 13.6 & 47.5 \\
\hline Hand hoeing twice & 46.4 & 33.0 & 8.7 & 413.1 & 185.4 & 31.9 & 12.3 & 44.2 \\
\hline Unweeded control & 35.9 & 25.3 & 6.8 & 310.1 & 137.0 & 18.9 & 8.6 & 27.5 \\
\hline LSD at 0.05 & 4.2 & 2.84 & 0.83 & 9.57 & 12.23 & 2.27 & 1.56 & 3.90 \\
\hline
\end{tabular}




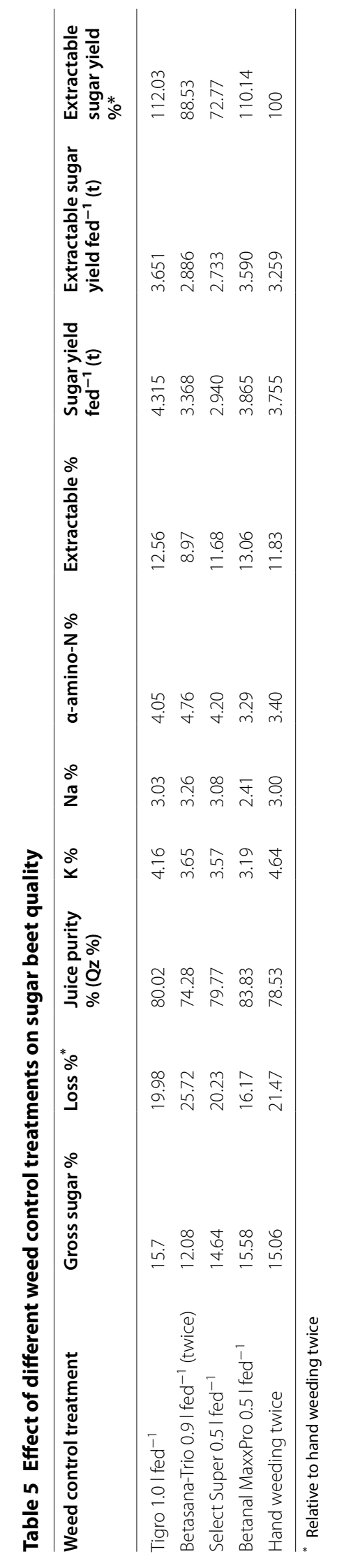


$1.01 \mathrm{fed}^{-1}$ and Betasana-Trio $0.91 \mathrm{fed}^{-1}$ produced high values of root yield $t$ fed ${ }^{-1}$. These treatments significantly increased root yield $\mathrm{t}$ fed ${ }^{-1}$ over the unweeded check by 79.4, 68.8, 42.9 and 33.9\%, respectively (Table 4); however, the differences among Betanal MaxxPro and hand hoeing twice were insignificant in their effect on shoot yield $\mathrm{fed}^{-1}$. In this connection, the maximum significant increase in biological yield $\mathrm{t} \mathrm{fed}^{-1}$ was obtained by Betanal MaxxPro (72.7\%) followed by hand hoeing twice (60.6\%), Tigro at $1.01 \mathrm{fed}^{-1}(48.7 \%)$ and Betasana-Trio $0.9 \mathrm{l} \mathrm{fed}^{-1}(27.6 \%)$ in comparison with unweeded treatment. Insignificant differences were noticed between Betanal MaxxPro and hand hoeing twice. The obtained results clearly indicated that the application of Betanal MaxxPro, hand hoeing twice, Tigro at $1.01 \mathrm{fed}^{-1}$ (48.7\%) and Betasana-Trio $0.91 \mathrm{fed}^{-1}$ was the best treatment in weed elimination and increasing root yield fed ${ }^{-1}$.

\section{Sugar beet root quality.}

Data in Table 5 and Fig. 1 show that weed control treatments exhibited clear differences in sugar beet quality parameters, which affected sugar extraction. Gross sugar $\%$ ranged between 12.08 and $15.7 \%$ and extractable sugar $\%$ ranged between 8.97 and $13.8 \%$ for Betasana-Trio at $0.09 \mathrm{l} \mathrm{fed}^{-1}$ and Betanal MaxxPro at $0.5 \mathrm{l} \mathrm{fed}^{-1}$. The highest sugar beet sugar yield resulted from the herbicidal treatment with Betanal MaxxPro or Tigro at $1.0 \mathrm{l}$ $\mathrm{fed}^{-1}$, which gave the greatest gross and extractable sugar yield $\mathrm{fed}^{-1}$ and exceeded the hand weeding treatment by 10.4 and $7.8 \%$. Weed treatment with Betanal MaxxPro resulted in the highest contained the highest gross sugar $\%$, extractable sugar $\%$, the highest purity $83 \%$ and the lowest low soluble non-sugars (potassium, sodium and $\alpha$-amino nitrogen content of beet). Data in Table 5 and Fig. 2 show that weed control treatments exhibited clear differences in sugar beet quality parameters, which affected sugar extraction. The highest sugar beet yield resulted from Tigro at $1.0 \mathrm{l} \mathrm{fed}^{-1}$ followed by hand weeding twice, which gave the greatest sugar yield fed ${ }^{-1}$.

\section{Discussion}

The results of weed flora indicated that the dominant weed species were related to broadleaf. Several investigators reported that approximately $70 \%$ of weed species in sugar beet fields are mainly broadleaf annual such as redroot pigweed (Amaranthus retroflexus) (Weaver and Williams 1980; Schwizer and May 1993 and Heidari et al. 2007; Lobmann 2019).

Weed elimination in sugar beet was achieved by Betasana-Trio and Tigro herbicides as well as Select Super herbicide. These results indicated and confirmed that Betasana-Trio and Tigro herbicides are specified to broadleaved weeds. Similar tendency was recorded for the narrow-leaved weeds where these results indicated and confirmed that Select Super herbicide is specified to narrow-leaved weeds. Mousa et al. (2015) reported that all weed control treatments decrease significant various weeds categories than untreated check and hand hoeing twice was the most superior treatment on reducing the fresh weight of weeds species in both seasons, and gave significant effect on the second one only. Hand hoeing twice gave the highest significant percentage with Rumex dentatus and Chenopodium murale by 83 and $90 \%$, respectively, compared to untreated control. Also, he added that the total broadleaf and total broadleaf and grassy weeds were significantly reduced by 54 and $91 \%$, respectively, compared to untreated check in the second season. Our findings are consistent with those obtained by Attia et al. (2011), Vasel et al. (2012), Wujek et al. (2012) and Deveikte et al. (2015).

Regarding the effect of herbicidal treatments on sugar beet leaf pigmentation, the results indicated that although the mode of action of most of these herbicides is a classical photosynthesis inhibitor, they possessed higher selectivity and did not affect sugar beet leaf chlorophyll content; meanwhile, all of the treatments surpassed the control. Such superiority in chlorophyll content may be due to the lesser competition between sugar beet plants and the associated weeds as indicated in Table 3). The results emphasized that all the herbicidal treatments except Tigro at the lower dose did not affect sugar beet pigmentation of leaves. Chitband et al. (2014) reported that PSII inhibitor herbicide such as chloridazon controlled weeds at higher doses more than other herbicides (except of Portulaca oleracea) by 90 percent reduction in aboveground dry matter yield.

Applying Betanal MaxxPro, hand hoeing twice, Tigro at $1.0 \mathrm{l} \mathrm{fed}^{-1}$ and Betasana-Trio $0.91 \mathrm{fed}^{-1}$ produced high values of root yield $t \mathrm{fed}^{-1}$. These treatments significantly increased root yield $\mathrm{t}$ fed ${ }^{-1}$ over the unweeded check by $79.4,68.8,42.9$ and $33.9 \%$, respectively. Such superiority of these treatments in increasing sugar beet yield characters may be due to the lesser coemption of weeds to sugar beet, especially at the early growth stages, which reflected on number and weights of the different species. Similar results were obtained by Soroka and Gadzhiev (2006) who reported that when sugar beet and weeds grow together 30 days after emergence of sugar beet, the root yield decreased by up to $45 \%$. Also, Attia et al. (2011) and Majidi et al. (2011) reported that the use of herbicides may reduce yield losses, as herbicides can reduce the weed infestation. Mehmeti (2004) showed that using a combination of broadleaved herbicides caused weeds to be controlled and root yield to be increased. These results are in accordance with those recorded by Wujek et al. (2012), Mobarak et al. (2012) and Abou-Zied et al. (2017). 


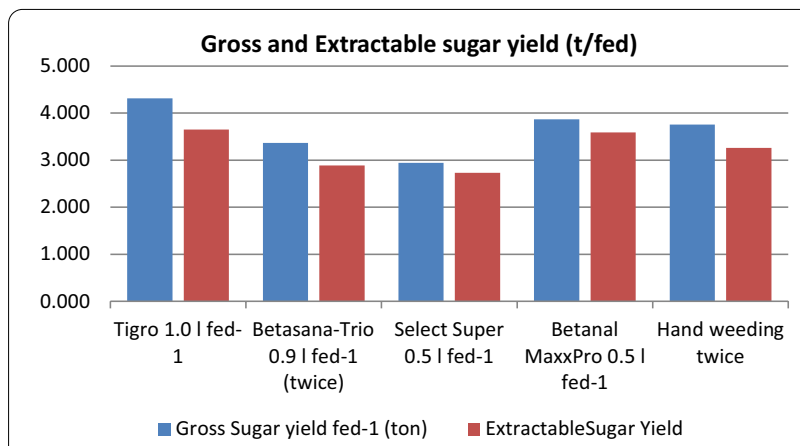

Fig.1 Effect of different weed control treatments on gross and extractable sugar yield $\mathrm{fed}^{-1}(\mathrm{t})$

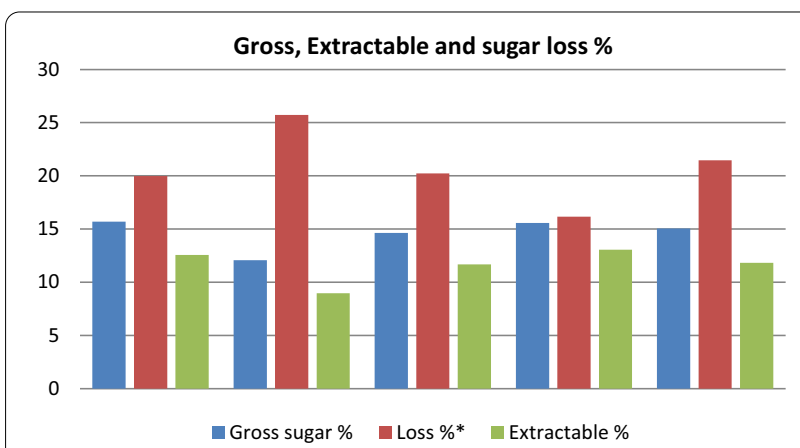

Fig. 2 Effect of different weed control treatments on gross and extractable sugar yield $\mathrm{fed}^{-1}(\mathrm{t})$

The data of the effect of weed control treatments on sugar beet root quality exhibited clear differences in sugar beet quality parameters, which affected sugar extraction process. In general, although the weed treatment with Betanal MaxxPro contained the highest gross sugar \%, it could not compensate the relatively lower yield to achieve the highest sugar yield $\mathrm{fed}^{-1}$. It seems that $\alpha$-amino- $\mathrm{N}$ component is related to sugar detracting, where it lowers the Qz \% parameter. Sugar beet plants treated with Betanal MaxxPro possessed the maximum purity parameters (high Qz \% and low soluble non-sugars (potassium, sodium and $\alpha$-amino nitrogen content of beet). This resulted in the superiority of gross and extractable sugar yields fed ${ }^{-1}$. In this respect, Dale et al. (2005) found that white sucrose produced per unit area did not differ among post-herbicide treatments and sugar and non-sugar contents were not affected by the herbicide treatments. It was reported that sugar yield values followed that of root yield because the herbicide did not have any influence on the amount of sugar beet root quality parameters (Dale et al. 2006).

Moreover, Dale et al. (2005) found that white sucrose produced per unit area did not differ among post-herbicide treatments and sugar and non-sugar contents were not affected by the herbicide treatments. Sugar yield values followed that of root yield because the herbicide did not have any influence on the amount of sugar beet root quality parameters (Dale et al. 2006). Mahmoud and Soliman (2012) indicated that sugar yield per feddan in the first season increased in five treatments (crus $2.5 \mathrm{~kg}$ $\mathrm{fed}^{-1}+$ handweeding, Betanal MaxxPro + hand hoeing, hand hoeing twice, crus $2.0 \mathrm{~kg} \mathrm{fed}^{-1}+$ handweeding and crus $2.5 \mathrm{~kg} \mathrm{fed}^{-1}$ ) as they gave 5.4, 4.98, 4.73, 4.64 and $4.35 \mathrm{t} \mathrm{fed}^{-1}$, respectively, with percentage from unweeded check 251.87, 232.02, 220.56, 216.33 and 202.64\%, respectively. The unweeded check gave the least sugar yield per feddan $\left(1.7 \mathrm{t} \mathrm{fed}^{-1}\right)$; also harness and crus $2.0 \mathrm{~kg}$ $\mathrm{fed}^{-1}$ gave lower sugar yield than the rest of treatments (2.64 and $2.84 \mathrm{t} \mathrm{fed}^{-1}$, respectively) with percentage from unweeded check 155.15 and $166.79 \%$, respectively.

\section{Conclusion}

Weed elimination in sugar beet was achieved by Betasana-Trio and Tigro herbicides as well as Select Super herbicide. Although the mode of action of most of the herbicides used is a classical photosynthesis inhibitor, they possessed higher selectivity and did not affect sugar beet leaf chlorophyll content. Applying Betanal MaxxPro, hand hoeing twice, Tigro at $1.0 \mathrm{l} \mathrm{fed}^{-1}$ and Betasana-Trio $0.91 \mathrm{fed}^{-1}$ produced high values of root yield $\mathrm{t} \mathrm{fed}^{-1}$. Sugar beet root quality exhibited clear differences in sugar beet quality parameters, which affected sugar extraction process. In general, although the weed treatment with Betanal MaxxPro contained the highest gross sugar \%, it could not compensate the relatively lower yield to achieve the highest sugar yield $\mathrm{fed}^{-1}$.

\section{Acknowledgements}

The authors would like to thank Research and Production Station, National Research Centre, Al-Emam Malek village, Nubaria District, team for their facilities during this work.

\section{Authors' contributions}

EMA, MSA and IME designed and implemented the field trials. BBM statistically analyzed the data and contributed significantly to the conception and design of the study. EMA, MSA, BBM and IME shared in the interpretation of data and the drafting and revision of the manuscript. All authors read and approved the final manuscript.

\section{Funding}

This paper is a part of the research project under title: Improvement of yield and quality traits of sugar beet using some agricultural treatments in Nubaria No. 11030124 funded by NRC from 2016 to 2019.

\section{Availability of data and materials}

The datasets supporting the results are included within the article.

\section{Consent for publication}

Not applicable.

\section{Ethics approval and consent to participate}

The authors declare that the work is ethically approved and consent to participate. 


\section{Competing interests}

The authors declare that they have no competing interests.

\section{Author details}

${ }^{1}$ Field Crops Res. Dept., Agric. Div., National Research Centre, 33 El-Behooth St., Giza, Egypt. ${ }^{2}$ Botany Department, Agric. Div., National Research Centre, 33 El-Behooth St, Giza, Egypt.

Received: 21 Auqust 2020 Accepted: 21 December 2020 Published online: 13 January 2021

\section{References}

Abo El-Hassan RGM (2010) Improving the efficiency of some herbicides in weed control in sugar beet by some adjuvants. M Sc Thesis Fac Agric Cairo Univ Egypt. https://doi.org/10.5829/idosi.aejaes.2016.16.6.12979

Abou-Zied KhA, Abd El-All AEA, Osman AM (2017) Response of sugar beet yield and water use efficiency to deficit irrigation and weed competition under drip irrigation system. J Plant Production Mansoura Univ 8 (12): 1295-1302 Available at: http:Library.mans.edu.eg/eulc_v5/Libraries/start.

Attia AN, Said EM, Seadh SE, El-Maghraby SS, Ibrahim ME (2011) Effect of sowing methods and weed control treatments on growth of sugar beet and weed characters under nitrogen fertilizer levels. J Plant Production Mansoura Univ 2(6):773-785

Bezhin KH, Santel J, Gerhards R (2015) Evaluation of two chemical weed control systems in sugar beet in Germany and the Russian Federation. Plant Soil Environ 6(11):489-495. https://doi.org/10.17221/482/2015-PSE

Chitband AA, Ghorbani R, Rashed MH, Abbaspoor MA, Abbasi R (2014) Evaluation of broadleaf weeds control with selectivity of post-emergence herbicides in sugar beet (Beta vulgaris L.). Not Sci Biol 6(4):491-497. https ://doi.org/10.1583/nsb649457

Cioni F, Maines G (2011) Weed control in sugar beet. Sugar Tech 12:243-255. https://doi.org/10.1007/s12355-010-0036-2

Dale TM, McGrath JM, Renner KA (2005) Response of sugar beet varieties and populations to post emergence herbicides. J Sugar Beet Res 42:119-126

Dale TM, Renner KA, Kravchenko AN (2006) Effect of herbicides on weed control and sugar beet (Beta vulgaris L.) yield and quality. Weed Technol 20(1):150-156. https://doi.org/10.1614/wt-04-278r1.1

Deveikte I, Seibutis V, Feiza V, Feiziene D (2015) Control of annual broadleaf weeds by combinations of herbicides in sugar beet. Zemdirbyste-Agriculture 102(2):147-152. https://doi.org/10.13080/z-a.2015.102.019

Heidari GH, Nasab ADM, Javanshir A, RahimzadehKhoie F, Moghaddam M (2007) Influence of redroot pigweed (Amaranthus retroflexus L.) emergence time and density on yield and quality of two sugar beet cultivars. J Food Agric Environ 5(3 \& 4):261-266

Jalali AH, Salehi F (2013) Sugar beet yield as affected by seed priming and weed control. Arch Agron Soil Sci 59:281-288. https://doi. org/10.1080/03650340.2011.608158

Jursík M, Holec J, Soukup J, Venclová V (2008) Competitive relationships between sugar beet and weeds in dependence on time of weed control. Plant Soil Environ 54(3):108-116. https://doi.org/10.17221/2687-PSE

Kobusch H (2003) Unkrautbekämpfung in Zuckerrüben - Ermittlung der Kritischen Periode. [Ph D Thesis] Hohenheim Universität Hohenheim. https://doi.org/10.11648/j.jps.20180604.15

Lobmann A, Christen O, Petersen J (2019) Development of herbicide resistance in weeds in a crop rotation with acetolactate synthase-tolerant sugar beets under varying selection pressure. Weed Res Soc 59:479-489. https://doi.org/10.1111/wre.12385
Lodovichi MV, Blanco AM, Chantre GR, Bandoni JA, Sabbatini MR, Vigna M, López R, Gigón R (2013) Operational planning of herbicide-based weed management. Agric Sys 121(2):117-129

Mahmoud S, Soliman S (2012) Chemical weed control in sugar Beet. Alex Sci Exchange J 33(4):341-348

Majidi M, Heidari G, Mohammadi K (2011) Management of broad- leaved weeds by combination of herbicides in sugar beet production. Adv Environ Biol 5(10):3302-3306

Majidi M, Heidari G, Emam Y (2017) Qualitative characteristics of sugar beet as affected by different broadleaf herbicides combinations. Iran Agric Res $36(2): 1-6$

May MJ (2001) Crop protection in sugar beet. Pesticide Outlook 188-191. Google Scholar

May MJ (2003) Economic consequences for UK farmers of growing GM herbicide tolerant sugar beet. Ann Appl Biol 142:41-48

Mehmeti A (2004) Three-year average effects of herbicides on weeds in potato and the yield of the crop. Herbol 5(1):85-94

Co M (2013) Manual for Chlorophyll Meter SPAD-502 plus. Minolta Camera Co Osaka Japan. https://doi.org/10.2312/enmap.2015.010

Mobarak OM, Galal AH, Mekky MS, Motagally FM (2012) Various methods for determining the critical period of weed infestation to sugar beet. The 4th field crops conference "Field crops facing future challenges." Egyptian J Agric Res 90(4):515-530

Mousa RA, Tagour RMH, Fakar AO (2015) Efficacy of irrigation intervals and weed control treatments on sugar beet (Beta vulgaris $\mathrm{L}$ ) productivity. Alex J Agric Res 60(3):253-268

MSTAT-C (1988) MSTAT-C, a microcomputer program for the design, arrangement and analysis of agronomic research. Michigan State University East Lansing https://www.canr.msu.edu/afre/projects/microcomputer_stati stical_package_mstat._1983_1985

Petersen J (2008) A review on weed control in sugar beet. Weed Biol Manage. https://doi.org/10.1007/978-94-017-0552-3_23

Schweizer E, Dexter A (1987) Weed control in sugar beets (Beta vulgaris) in North America. Rev Weed Sci 3:11-33

Schweizer EE, May MJ (1993) Weeds and Weed Control. In Cooke DA, Scott RK (eds) The sugar beet crop: science into practice. Chapman and Hall, London, pp 485-519. https://doi.org/10.1007/978-94-009-0373-9_12

Soroka SV, Gadzhieva GJ (2006) State of weed infestation and features of sugar beet protection in Belarus. Proc Nat Sci 110:165-172. https://doi. org/10.2298/ZMSPN0610165S

Tagour RMH, Abd El-Hamed GM, Mousa RA, Sarhan HM (2012) Integration effects of mulching and burning with hoeing on sugar beet and associated weeds. J Plant Prod Mansoura Univ Egypt 3(5):715-727

Vasel EH, Ladewig E, Märländer B (2012) Weed composition and herbicide use strategies in sugar beet cultivation in Germany. J Kulturpflanzen 64(4):112-125. https://doi.org/10.5073/JfK.2012.04.02

Weaver SE, Williams EL (1980) The biology of Canadian weeds: Amaranthus retroflexus L., Amaranthus powellii S. Wats. and Amaranthus hybridus L. Can I Plant Sci 60:1215-1234. https://doi.org/10.4141/cjps80-175

Wujek B, Kucharski M, Domaradzki K (2012) Weed control programs in sugar beet (Beta vulgaris L.): influence on herbicidal residue and yield quality. J Food Agric Enviro 10(3 \& 4):606-609

\section{Publisher's Note}

Springer Nature remains neutral with regard to jurisdictional claims in published maps and institutional affiliations. 